Uganda Journal of Agricultural Sciences by National Agricultural Research Organisation is licensed under a Creative Commons Attribution 4.0 International License. Based on a work at www.ajol.info

\title{
A bioeconomic analysis of the carbon sequestration potential of agroforestry systems: A case study of Grevillea robusta in South Western Uganda
}

\author{
I. Kiyingi ${ }^{1}$, D. Ocama ${ }^{1}$, D. Mujuni ${ }^{1}$ and K. Nyombi ${ }^{2}$ \\ ${ }^{1}$ National Forestry Resources Research Institute, NaFORRI, P. O. Box 1752, Kampala, Uganda \\ ${ }^{2}$ School of Forestry, Environment and Geographical Sciences, Makerere University, \\ P. O. Box 7062, Kampala, Uganda
}

Author for correspondence: ikiyingi_2000@yahoo.com

\begin{abstract}
Grevillea robusta is an agroforestry tree species that has been widely promoted under the carbon forestry schemes in South Western Uganda. The objective of the study was to estimate the amount of carbon sequestered and the profitability of carbon offsets in $G$ robusta woodlot and agroforestry management options under the Plan Vivo system and small-scale Clean Development Mechanism (CDM). An allometric equation for $G$ robusta was used to calculate the carbon stocks and merchantable wood volume in the woodlot and agroforestry management options over different crediting periods. The results indicated that $G$ robusta woodlots and agroforestry management options sequestered 470 and $225 \mathrm{t} \mathrm{CO}_{2} \mathrm{e} \mathrm{ha}^{-1}$ respectively, over a 20 year rotation. The net present values (NPVs) of the $G$ robusta agroforestry management option of US\$4367 and 4447 ha $^{-1}$ under the Plan Vivo and small-scale CDM, respectively, were higher than US\$1358 and $1902 \mathrm{ha}^{-1}$ in the $G$ robusta woodlot management option. The NPV of the traditional agroforestry system was US\$3992 $\mathrm{ha}^{-1}$. These results show that, whereas the woodlot option stores more carbon, it is the least profitable option. Analysis also revealed that, although poor households were well represented in the Plan Vivo scheme, they preferred the agroforestry option. This suggests that forest carbon offsets on productive agricultural land, should focus on promoting agroforestry technologies in order to increase profitability and targeting of the poor households.
\end{abstract}

Key words: Allometric equation, carbon offsets, profitability 


\section{Introduction}

There is increasing concern about the devastating effects of climate change on the environment, human health and food security (UNFCCC, 2008). It is widely accepted that climate change is closely linked to increased concentrations of atmospheric carbon dioxide $\left(\mathrm{CO}_{2}\right)$ and other greenhouse gases (Schmitt-Harsh et al., 2012). Afforestation and reforestation have been considered as some of the measures for climate change mitigation under the Kyoto Protocol (Biocarbon Fund, 2011). Planting trees that are able to sequester greenhouse gases, such as carbon dioxide, is one of the options of mitigating climate change. The carbon sequestered by forest plantations and agroforestry systems can be traded under voluntary emissions reductions (VERs) or certified emission reductions (IPCC, 2007).

In South Western Uganda, the Environmental Conservation Trust of Uganda (ECOTRUST) has been implementing a voluntary carbon scheme under the Plan Vivo land system. The Plan Vivo system is a framework for planning, managing and monitoring the supply of Voluntary Emissions Reductions (VERs) from community based sustainable landuse projects (Carter, 2009). Similarly, the National Forestry Authority and other forest companies have been implementing the certified carbon scheme under the Clean Development Mechanism (CDM) (Peskett et al., 2011). CDM is one of the market-based instruments designed by the Kyoto Protocol to ensure developed countries support joint implementation of climate mitigation projects to meet their agreed emission targets.

Grevillea robusta is among the tree species that have been widely promoted in the carbon offset schemes in Uganda. The species has also been promoted widely as shade trees for banana and coffee farming systems. Consequently, many tree farmers have adopted $G$. robusta in woodlot and agroforestry management options.

Several studies have investigated the amount of carbon that can be stored in forest carbon offsets (Aune et al., 2004; De Jong et al., 2005; Shiufa et al., 2010; Glomsrod et al., 2011; Vonada et al., 2011), while others have investigated the profitability of the carbon offsets (Palmer and Silber, 2012; Schmitt-Harsh et al., 2012). However, to our knowledge, no study has specifically assessed the carbon sequestration potential of G. robusta under woodlot and agroforestry management options and under alternative carbon accounting systems. Therefore, this study was aimed at determining the amount of carbon sequestered, financial profitability of Grobusta under alternative management options and accessibility of forest carbon offsets in Uganda.

\section{Methodology}

\section{Study area}

The study was conducted in Rubirizi, Mitoma and Kabale districts in SouthWest Uganda, lying approximately between $00^{\circ} 162 \mathrm{~S} 30^{\circ} 062 \mathrm{E}$ and $00^{\circ} 362$ $\mathrm{S} 30^{\circ} 002 \mathrm{E}$. The total population in the 3 districts is 643,928 (UBOS, 2017) and the main agricultural activity in these areas is growing coffee and bananas, intercropped with other crops and tree species (Fisher, 2013).

Several farm forestry projects have been implemented in the study area, with the common aim of improving rural household income and livelihood. The Farm Income Enhancement and Forest 
Conservation Project (FIEFOC) and the 'Trees for Global benefits' (TGB) project are the two major farm forestry projects that have been implemented in the study area. One of the objectives of the FIEFOC project was to improve rural household incomes, and livelihood, by providing an enabling environment for small-scale farming households to participate in tree planting for wood supply and environmental protection (OAG, 2011). This was achieved through provision of free tree seedlings and forestry advisory services to farming households in rural areas.

The TGB project was a community payment for Ecosystem Services (PES) scheme linking small-scale landholder farmers to the voluntary carbon market (Schreckenberg et al., 2013). The project contracted farmers to plant a variety of indigenous tree species in order to sell voluntary emissions reductions on the voluntary carbon market. The project has more than 1500 registered participants using the Plan Vivo land use system (Schreckenberg et al., 2013).

\section{Data collection}

A face-to-face questionnaire survey was conducted among tree farmers in Rubirizi and Mitooma districts to collect economic data on the quantity, price and flow of farm outputs (timber production, firewood) and transaction costs associated with G. robusta wood lots, G. robusta agroforestry and the traditional agroforestry systems. Stratified random sampling was used to select households for questionnaire interviews. The households were randomly sampled from lists of G. robusta tree farmers, according to their population proportions by district. The sampling frame for the households growing $G$. robusta under the different management options was provided by the district forest department staff and local leaders. Accordingly, 78, 86 and 88 respondents were sampled in the two districts from the G. robusta woodlot, $G$. robusta agroforestry and traditional agroforestry categories, respectively.

The questionnaire survey was complemented by focus group discussions (FGDs) with G. robusta farmers and Key informant interviews (KII) with district forest department and ECOTRUST staff. The FGDs provided information about the typical management regimes, carbon payments schedules and institutional arrangements within the carbon offset schemes. Key informant interviews provided information about technical specifications for tree farming under the projets, such as tree species, tree spacing and number per hectare and expected sequestered carbon.

\section{Biomass inventory}

Tree inventory data were collected from G. robusta tree farmers in Rubirizi, Mitooma and Kabale districts in South Western Uganda. The data collected from G. robusta woodlots and agroforestry gardens included plantation area (hectares), age of trees and diameter at breast height $(\mathrm{dbh})$. The data were collected from plantations of 15 to 20 years of age. District forest department staff and NGO staff in the study area provided information about the location of plantations of known age. Tree inventory data, including number of merchantable trees per plot, were also collected from traditional agroforestry gardens. The data were collected from 53,59 and 86 plots of G.robusta woodlots, G.robusta agroforestry gardens and traditional agroforestry gardens, respectively. Plot size was $20 \mathrm{~m} \times 20 \mathrm{~m}$. The number of 
plots established on each farm depended on the farm size.

\section{Data analysis}

\section{Estimation of biomass stock}

Above-ground biomass (AGB) for individual G. robusta trees was computed based on the allometric equation (Tumwebaze et al., 2013) represented as:

$$
\ln T A G B=0.01+1.81 \ln (D B H)
$$

Where:

ln is natural logarithm, DBH is diameter at breast height and TAGB is total above ground biomass

The below ground biomass component (root system) is accounted for by multiplying the above ground biomass stock by a specific root factor. Belowground root biomass is estimated as $20 \%$ of the above-ground tree biomass (IPCC, 2007). The below-ground biomass was added to the estimated above-ground biomass to obtain an estimate of the total biomass. Oven-dry matter was converted to carbon stock in above-ground tree biomass (CSTAG) using conversion factor (CF) of 0.50 (Brown, 1997; IPCC, 2007).

$C S T_{A G}=W_{\text {ovendry }} * C F C$

Where:

$C S T_{A G}$ is carbon stock in above-ground tree biomass; $W_{\text {ovendry }}$ is the oven-dry weight of above-ground tree biomass; $C F C$ is conversion factor (0.50).

The total carbon dioxide equivalent in above-ground and below-ground tree biomass was calculated as:

$$
C_{\text {TREE }}=\frac{44}{----} *\left(C S_{T A G}+C S_{T B G}\right)
$$

Where:

$C_{\text {TREE }}$ is carbon in above and belowground biomass in trees $(\mathrm{tCO} 2 \mathrm{e}) ; C S_{\text {TAG }}$ Carbon stock in above-ground tree biomass (tC); $C S_{T B G}$ Carbon stock in below ground biomass in tree roots $(\mathrm{tC})$; $44 / 12$ is the Ratio of molecular weights of $\mathrm{CO}_{2}$ and carbon, which was converted to carbon by assuming $50 \%$ carbon content (IPCC, 2003).

Individual tree carbon stock was summed to plot level and then extrapolated to a hectare. Due to insufficient data on G. robusta trees above 20 years, the current annual increment at 20 years under the different management options, was used to project carbon stock and tree volume to 25 years.

Estimation of G. robusta timber volume The above ground oven dry biomass was converted to merchantable biomass using the biomass expansion factor of 1.4 (IPCC, 2003) as:

Above ground biomass

Merchantable biomass --oxpansion factor
Biomass expans

The merchantable biomass was converted to merchantable volume using an average wood density of $630 \mathrm{~kg} \mathrm{~m}^{-3}$ (IPCC, 2007). Merchantable tree volume was estimated as:

$$
\text { Merchantable biomass (kg) }
$$

$$
\text { Volume }=\text { Wood density }\left(\mathrm{kg} \mathrm{m}^{-3}\right)
$$




\section{Valuation of products}

The harvests from the different management options were valued using the farm gate prices. Harvestable shade trees in the traditional agroforestry system were valued based on their timber grade, size and number of standing trees per hectare. This was based on the fact that there is a substantial difference between the residual values of different tree species. To ease analysis, the residual value of shade trees was assumed to be evenly spread throughout the rotation. Food crop production in the base year was also assumed to represent the rest of the rotation. In this study, household income includes cash sales and value of home consumed production.

\section{Economic model}

The profitability of the three options was estimated using the Net Present Value (NPV). To make the alternatives comparable over time, the costs and benefits were discounted into a present value over 20 and 25 year crediting periods under CDM and Plan Vivo carbon accounting systems respectively (Gittinger, 1982; Graves, 2007). A discount rate of $10 \%$ and 2016 constant prices were used in the base case scenario. The net present value (NPV) is represented as:

$N P V=\sum_{t=0}^{t=n} \frac{B_{t}-C_{t}}{(1+p)^{t}}$

Where:

$\mathrm{B}=$ Benefit; $\mathrm{C}=$ Cost $; \mathrm{t}=$ Production Period or time in years; $p=$ Discount Rate; $\mathrm{n}=$ Rotation length in years.

\section{Results and discussion}

\section{Participation of vulnerable groups in TGB project}

Households were assigned to quantiles (Table 2) using household income and the same bounds calibrated from the Uganda National Household Survey (MFPED, 2014). Overall, the poor households were well represented in the TGB project in terms of numbers. About $35 \%$ of the project participants were poor (Table 2), which was above the national average of $24.5 \%$ in 2014 (MFPED, 2014). However, closer scrutiny revealed that poor households were better represented in the agroforestry than the woodlot category. Focus group discussions indicated that poor households, with small land holdings, preferred the agroforestry option where trees can be integrated with agricultural crop production. The agroforestry option provides a more continuous cash flow from agricultural production, which is essential for their survival. Conversely, it was observed that $G$. robusta woodlots were mainly adopted by the non-poor households, which had land to spare for woodlots after growing food crops. This suggests that the carbon forestry projects need to focus on agroforestry management options in order to increase targeting of the poor households.

The results also indicated low participation (less than $22 \%$ ) of youth (18 - 35 years) and the female headed households (Table 2). The low participation of youth was attributed to the fact that only few of them owned land. On the other hand, the low percentage of female headed households participating in the TGB project is approximately equal to the share of female headed households 
Table 1. Base-case assumptions and parameter values for G.robusta and traditional system in South Western Uganda

\begin{tabular}{|c|c|c|c|c|c|}
\hline \multirow[t]{2}{*}{ Description } & \multicolumn{2}{|c|}{ Grevillearobusta } & \multicolumn{2}{|c|}{ Traditional system } & \multirow[t]{2}{*}{ Source } \\
\hline & Value & Units & Value & Units & \\
\hline CDM carbon price & 4.15 & $\mathrm{US} \$ / \mathrm{tCO}_{2} \mathrm{e}$ & - & - & Tennigkeit and Windhorst (2007) \\
\hline Stumpage price & 30 & $\mathrm{US} \$ \mathrm{~m}^{-3}$ & $(40-0)$ & US\$/tree & Field data collection \\
\hline Price of firewood & 5 & $\mathrm{US} \$ \mathrm{~m}^{-3}$ & 5 & $\mathrm{US} \$ \mathrm{~m}^{-3}$ & Field data collection \\
\hline Discount rate & 10 & $\%$ & 10 & $\%$ & Gittinger, 1982; Cacho et al., 2005 \\
\hline Baseline carbon & 9 & $\mathrm{tCO}_{2} \mathrm{e} \mathrm{ha}{ }^{-1}$ & - & $\mathrm{tCO}_{2} \mathrm{e} \mathrm{ha} \mathrm{a}^{-1}$ & Hayward et al. (2009) \\
\hline Establishment costs & 356 & US\$ ha-1 & - & - & Field data collection \\
\hline CDM annual monitoring costs & 5 & US\$ ha-1 & - & US\$ ha-1 & Cacho et al., 2004; Biocarbon Fund, 2011 \\
\hline CDM contract establishment cost (under bundling) & 100 & US\$ & - & - & Biocarbon Fund (2011) \\
\hline Wood density & 630 & $\mathrm{~kg} \mathrm{~m}^{-3}$ & - & - & IPCC, 2003; Santos et al., 2004; Orwa et al., 2009 \\
\hline Wood carbon content & 0.5 & - & - & - & IPCC (2003) \\
\hline Biomass expansion factor & 1.4 & - & - & - & IPCC, 2003; Rawat et al., 2015 \\
\hline Planvivo carbon revenue & $(300-600)$ & US\$ ha-1 & - & - & Field data collection \\
\hline Net crop income & $0-374$ & US\$ ha-1 & 362 & US\$ ha-1 & Field data collection \\
\hline
\end{tabular}


in the population. Therefore, this may not sequestered 470 and $225 \mathrm{tCO}_{2} \mathrm{e} \mathrm{ha-1}$, reflect a lack of participation of female respectively over a 20 year rotation (Fig. headed households in the project.

\section{Carbon sequestration}

The results indicate that $G$. robusta woodlots and agroforestry gardens $1)$. The average merchantable wood volume accumulated in $G$. robusta woodlots and agroforestry gardens over the same period was 231 and $110 \mathrm{~m}^{3} \mathrm{ha}^{-1}$, respectively.

Table 2. Participation in TGB project by vulnerable groups

\begin{tabular}{|c|c|c|c|}
\hline \multicolumn{2}{|l|}{ Demographic group } & \multirow{2}{*}{$\begin{array}{l}\text { G. robusta } \\
\text { woodlot } \\
\text { Participant } \\
\text { distribution (\%) }\end{array}$} & \multirow{2}{*}{$\begin{array}{l}\text { G. robusta } \\
\text { agroforestry } \\
\text { Participant } \\
\text { distribution (\%) }\end{array}$} \\
\hline Population quantile & $\begin{array}{c}\text { National income } \\
\text { distribution (2014) }\end{array}$ & & \\
\hline Poor & 24.5 & 21.7 & 48.5 \\
\hline Insecure & 42.9 & 38.8 & 33.2 \\
\hline Middle class & 32.6 & 39.5 & 18.3 \\
\hline \multicolumn{4}{|l|}{ Gender } \\
\hline Male & & 85.8 & 79 \\
\hline Female & & 14.2 & 21 \\
\hline \multicolumn{4}{|l|}{ Age group } \\
\hline $18-35$ & & 21.3 & 20.6 \\
\hline 36 and above & & 78.7 & 79.4 \\
\hline
\end{tabular}

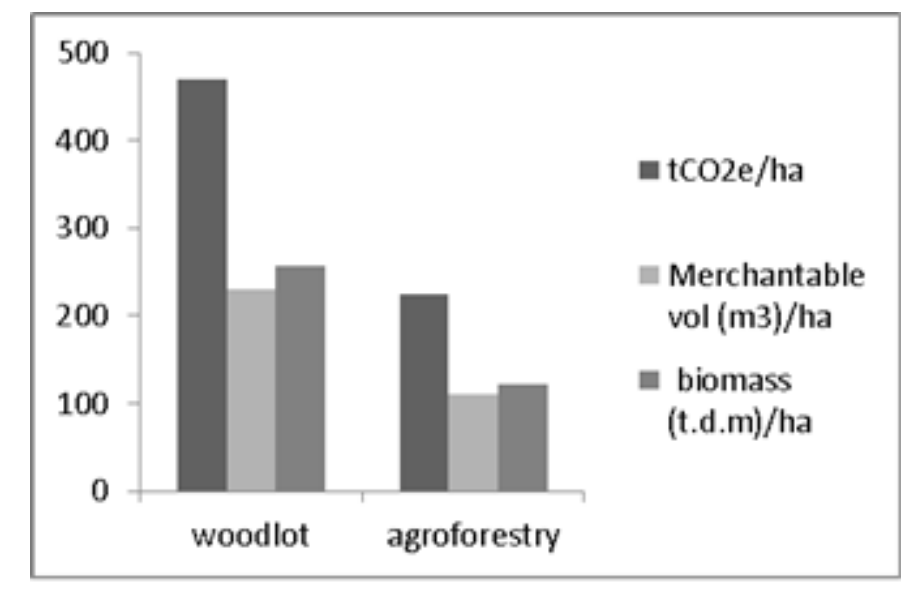

Figure 1. Merchantable wood volume $\left(\mathrm{m}^{3} \mathrm{ha}^{-1}\right)$ and carbon stocks in standing tree biomass $\left(\mathrm{tCO}_{2} \mathrm{e} \mathrm{ha}^{-1}\right)$ for $\boldsymbol{G}$ robusta at 20 years. 


\section{Carbon revenue}

The mean annual carbon revenue from G. robusta woodlots was US\$97.5 and $44.85 \mathrm{ha}^{-1} \mathrm{yr}^{-1}$ for CDM and PlanVivo systems, respectively (Fig. 2). This was higher than the mean annual carbon revenue from $G$. robusta agroforestry option of US\$46.6 and $44.6 \mathrm{ha}^{-1} \mathrm{yr}^{-1}$ for CDM and Plan Vivo systems, respectively. Mean carbon revenue from G. robusta woodlots contributed $18.2 \%$ to the overall mean annual revenue under the CDM carbon accounting system. In comparison, the mean carbon revenue from $G$. robusta woodlots contributed $5.7 \%$ to the overall mean annual revenue under the Plan Vivo carbon accounting system. In this study, income includes home consumed production and cash income.

\section{Profitability}

The discounted cash flows indicated that the NPVs of the 3 management options were positive under the assumptions analysed (Table 3). However, G. robusta agroforestry and woodlots under smallscale CDM with bundling had higher NPVs (US\$4447 and $1902 \mathrm{ha}^{-1}$ ) respectively, compared to US\$4367 and 1358 ha $^{-1}$ under the Plan Vivo system (Table 3).The results are robust to $15 \%$
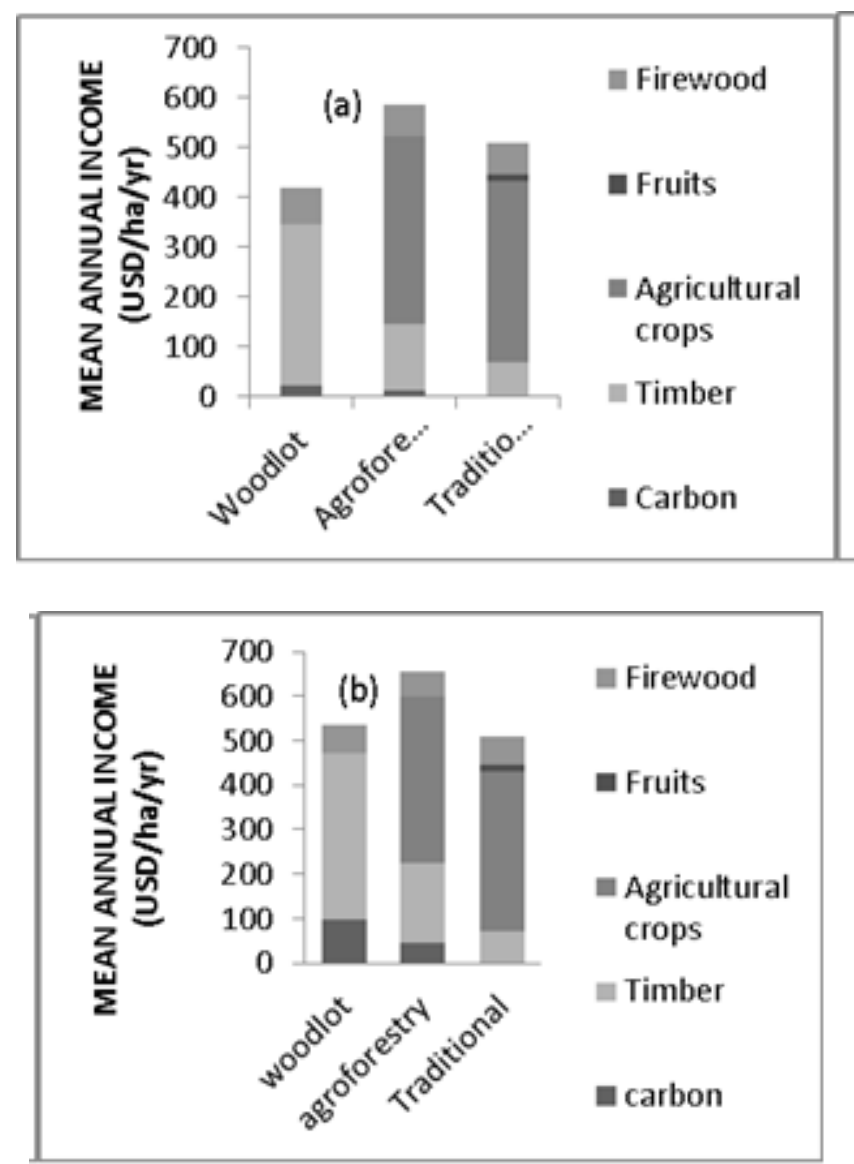

Figure 2. Contribution of carbon revenue to mean annual income under the PlanVivo (a) and CDM (b) carbon accounting systems. 
Table 3. Summary of cashflow for Grobusta and traditional agroforestry management options

\begin{tabular}{|c|c|c|c|c|c|}
\hline \multirow[t]{2}{*}{ Variable } & \multicolumn{2}{|c|}{ Plan Vivo } & \multicolumn{2}{|c|}{$\mathrm{CDM}$} & \multirow[t]{2}{*}{ Traditional } \\
\hline & $\begin{array}{l}\text { Agro- } \\
\text { forestry }\end{array}$ & Woodlot & $\begin{array}{l}\text { Agro- } \\
\text { forestry }\end{array}$ & Woodlot & \\
\hline NPV $($ US\$ ha-1) & 4367 & 1358 & 4447 & 1902 & 3992 \\
\hline \multicolumn{6}{|l|}{ Sensitivity } \\
\hline \multicolumn{6}{|c|}{$15 \%$ increase in timber value } \\
\hline NPV & 4423 & 1493 & 4640 & 2069 & 4021 \\
\hline \multicolumn{6}{|c|}{$6 \%$ increase in timber harvest } \\
\hline NPV & 4529 & 1650 & 4632 & 2117 & 4123 \\
\hline \multicolumn{6}{|c|}{$5 \%$ Discount rate } \\
\hline NPV & 7082 & 3388 & 6535 & 3979 & 6310 \\
\hline
\end{tabular}

increase in timber value, $6 \%$ increase in timber harvest and $15 \%$ increase in discount rate. These results imply that it is more profitable for $G$. robusta carbon forestry farmers to participate in the smallscale CDM, if they are assisted to bundle, than to participate in the Plan Vivo system. Therefore, efforts to enhance profitability of carbon forestry should focus on facilitating the process of bundling tree farmers together in sizable groups in order to reduce costs per project.

The results also show that the NPV of $G$. robusta woodlots option was consistently lower than for traditional agroforestry and G. robusta agroforestry options. These results show that, whereas the woodlot option stores more carbon (Fig. 1), it is the least profitable option. This suggests that at the current carbon price, carbon forestry initiatives on productive agricultural land should focus on promoting agroforestry technologies.

\section{Acknowledgement}

The study was financed by the National Agricultural Research Organisation (NARO) and National Forestry Resources Research Institute (NaFORRI) through the ATAAS project.

\section{References}

Aune, J.B., Alene, T.A. and Kamala, P.G. 2004. Carbon sequestration in rural communities. Journal of Sustainable Forestry 21:169-179.

Bio-Carbon Fund. 2011. Biocarbon fund experience: Insights from Afforestation and Reforestation Clean Development Mechanism Projects. Washington: BioCarbon Fund.http.//www.wbcarbon finance.org/docs/BioCarbon-FundLessons-Learned-LOW-RES.pdf.

Brown, S. 1997. Estimating biomass and biomass change in tropical forests: A 
primer. Rome, Italy: Food and Agriculture Organization of the United Nations. http.//www.fao.org/docrep/ w4095e/w4095e00.htm.

Cacho, O.J., Marshall, G.R. and Milne, M. 2005. Transaction and abatement costs of carbon-sink projects in developing countries. Environment and Development Economics 10(5):597614.

Cacho, O.J., Wise, R. and MacDicken, K. 2004. Carbon monitoring costs and their effect on incentives to sequester carbon through forestry.Mitigation and Adaptation Strategies for Global Change 9(3):273-293.

Carter, S. 2009. Socio-economic benefits in Plan Vivo projects: Trees for global benefits, Uganda. Plan Vivo Foundation and ECOTRUST Uganda, Kampala, Uganda.

De Jong, B.H., Castilo-Santiago, M.A. and Tipper, R. 2005. Application of the climafor approach to estimate baseline carbon emissions of a forest conservation project in selva Lacandona, Chiapas, Mexico. Mitigation and Adaptation Strategies for Global Change 10(2):265-278.

Fisher, J. 2013. Justice implications of conditionality in Payments for Ecosystem Services: a case study from Uganda.pp. 21-45. In: Sikor, T. (eds.). The justices and injustices of Ecosystem Services.Routledge, Abingdon, UK.

Gittinger, J.P. 1982. Economic analysis of agricultural projects. Washington: World Bank. http.//www.cabdirect. org/cabdirect/abstract/19866701851.

Glomsrød, S., Liu, G., Wei, T. and Aune, J.B. 2011. How well do tree plantations comply with the twin targets of the clean development mechanism? The case of tree plantations in Tanzania. Ecological Economics 70(6):1066-1074.

Graves, P.E. 2007. Environmental economics: A critique of benefit-cost analysis, Lanham Maryland: Rowman \& Littlefield. http.//www.amazon.com /Environmental-Economics-CritiqueBenefit-Cost-Analysis/dp/0742546 993.

Intergovernmental Panel on Climate Change (IPCC). 2003. Intergovernmental Panel on Climate Change: Good practice guidance for land use, Land-Use Change and Forestry. http.//www.ipcc-nggip.iges. or.jp/public /gpglulucf_files/ GPG_ LULUCF_FULL.pdf.

Intergovernmental Panel on Climate Change (IPCC). 2007. Climate Change 2007: Synthesis Report. Contribution of Working Groups I, II and III to the fourth assessment report of the Intergovernmental Panel on Climate Change. Geneva:IPCC. ISBN 2-9169-122-4.

Hayward. J., Osei, J. and Esimu, R. 2009. Plan Vivo standard validation audit report for Trees for Global Benefits project. Ecotrust Uganda, Kampala, Uganda.

Orwa, C., Mutua, A., Kindt, R., Samnadass, R. and Simons, A. 2009. Agroforestry tree database: A tree species reference and selection guide version 4.0. http.//www.worlda groforestry.org/publication/agro forestree-database-tree-speciesreference-and-selection-guideversion-40.

Palmer, C. and Silber, T. 2012. Trade-offs between carbon sequestration and rural incomes in the N'hambita Community Carbon Project, 
Mozambique. Land Use Policy 29(1):83-93.

Peskett, L., Schreckenberg, K. and Brown, J. 2011. Institutional approaches for carbon financing in the forest sector: Learning lessons for REDD+ from forest carbon projects in Uganda. Environmental Science and Policy 14:216-229.

Rawat, L., Kamboj, S. and Kandwal, A. 2015. Biomass expansion factor and root-to-shoot ratio of some tree species of Punjab, India. The Indian Forester 141(2): 146-153.

Santos, P.E.T., Geraldi, I.O. and Garcia, J.N. 2004. Estimates of genetic parameters of wood traits for sawn timber production in Eucalyptus grandis. Genetics and Molecular Biology 27(4): 567-573.

Schmitt-Harsh, M., Evans, T.P., Castellonos, E. and Randolph, J.C. 2012. Carbon stocks in coffee agroforests and mixed dry tropical forests in the western highlands of Guatamala. Agroforestry Systems 86:141-157.

Schreckenberg, K., Mwayafu, D.M. and Nyamutale, R. 2013. Finding equity in carbon sequestration: a case study of the trees for global benefits project. Uganda Coalition for Sustainable Development, Kampala, Uganda.

Shuifa, K., Wagner, E.J., Zhou, L., Yali, W. and Yan Z. 2010. The situations and potentials of forest carbon sinks and employment creation from afforestation in China. International Forestry Review 12(3):247-255.
Tennigkeit, C. and Windhorst, C. 2007. Current situation of AR CDM in East Africa. Report commissioned by the Overseas plantation centre for pulpwood. Kampala:Unique forestry consultants.

Uganda Bureau of Statistics (UBOS) 2017. The National Population and Housing Census 2014 - Area Specific Profile Series, Kampala, Uganda.

Ministry of Finance Planning and Economic Development (MFPED) 2014. Poverty Status Report 2014. Structural Change and Poverty Reduction in Uganda.http.// library.health.go.ug/download/file/fid/ 580728.

Office of the Auditor General (OAG) 2011. Value for Money Audit Report on the Management of the Farm Income Enhancement and Forest Conservation Project. Ministry of Water and Environment, Kampala, Uganda.

Tumwebaze, S.B., Bevilacqua, E., Briggs, R. and Volk, T. 2013. Allometric biomass equations for tree species used in agroforestry systems in Uganda. Agroforestry Systems 87:781-795.

UNFCCC. 2008. Outcome of the Bonn climate change talks. Available at: http://unfecc.int/meetings/bonn_june_ 2008/items/4378.php.

Vonada, R., Tommie, H. and Waage, S. 2011. Introduction to payments for ecosystem services: A Reference Book for Uganda. Forest Trends and The Katoomba Group. 